Instituto de Estudios Sociales Avanzados (CSIC)

Working Paper 95-12

Research actors and the state: research evaluation and evaluation of science and technology policies in Spain

Luis Sanz Menéndez

Instituto de Estudios Sociales Avanzados (CSIC)

Madrid, October 1995 


\title{
Spain
}

\section{Research actors and the state: research evaluation and evaluation of science and technology policies in Spain}

\author{
Luis Sanz-Menéndez
}

This paper describes the development of research evaluation in Spain. It assumes that research evaluation, and $R \& D$ policy and programme evaluation are embedded in the development of an $R \& D$ system and are characterised by general Spanish policy-making. Research evaluation in a context of delegation and as a self-organising system for research actors guaranteed by the state, has been strongly developed in the last few years; $R \& D$ policy and programme evaluation is less institutionalised. The explanation is linked to the sequence of reforms of the $R \& D$ system and to the set up of the first Spanish science and technology policy.

Luis Sanz-Menéndez is Research Fellow, Instituto de Estudios Sociales Avanzados (IESA), Consejo Superior de Investigaciones Científicas (CSIC), C/Alfonso XII, $\mathrm{n}^{\circ}$ 18, 28014 Madrid, Spain. Tel: +34 (1) $521.9160 / 9028$; Fax: +34 (1) 521.8103 Email: LSanz@pinarl.csic.es.

The author is indebted to M Bordons, C E Garcia, E Muñoz, $E$ Navas and B Presmanes for their comments, to S Kuhlmann, $M$ Boden and $M$ Fitzgibbon who acted as discussants of a presentation of this paper in a Workshop in Lisbon in June 1995; and to the participants from the Network on European Science and Technology Policy Evaluation for their criticisms; special mention to L Georghiou, P Larédo and A Rip for their suggestions for the second version and to Hugh Cameron who edited the paper. The author is responsible for any remaining deficiencies.

The support of the European Commission is acknowledged (HCM contract CHRX-CT93-0240) and the Spanish National R\&D Plan (projects SEC 93-0688 and SEC 94-0796)
7 HIS PAPER DESCRIBES some properties and characteristics of the Spanish system of research evaluation, with special reference to the evaluation of science and technology policies and programmes. The term research evaluation is connected to the idea of research management ${ }^{1}$ or decision preparation ${ }^{2}$ and it is assumed to be related to the properties of national systems of research.

While the Spanish R\&D system was underdeveloped, RTD (research and technological development) policy in general and research evalugtion in particular had been almost irrelevant activities. In the context of research system reforms in the mid-80s, research evaluation as appraisal, to guarantee the quality of research and the faimess of $R \& D$ funding, gained particular relevance.

During those years, increasing effort and resources for the R\&D system had been high on the agenda. RTD policy and programme evaluation were part of the general discourse but no specific forces pushed in favour of its implementation. Informal systems for management control had been used in addressing research policies and management of R\&D organisations. So Spain still lacks strong $R \& D$ programme and policy evaluation.

A comparison with UK practices and procedures of R\&D policy evaluation ${ }^{3}$ shows that these activities are underdeveloped in Spain. Examples of evaluation are fewer in number and significance, activities started more recently, and the institutionalisation is less formalised. Finally there is nothing similar to the ROAME (Rationale, Objectives, Appraisal, 


\begin{tabular}{|c|c|}
\hline \multicolumn{2}{|c|}{ Glossary of abbreviations } \\
\hline $\begin{array}{l}\text { ANEP } \\
\text { CDTI }\end{array}$ & $\begin{array}{l}\text { National Evaluation and Assessment Agency } \\
\text { Centre for Technological and Industrial } \\
\text { Development }\end{array}$ \\
\hline CICYT & Interministerial Commission for S\&T \\
\hline CNEAI & $\begin{array}{l}\text { National Commission for Evaluation of Research } \\
\text { Activity }\end{array}$ \\
\hline $\begin{array}{l}\text { CSIC } \\
\text { EPOC } \\
\text { FIS }\end{array}$ & $\begin{array}{l}\text { National Centre for Scientific Research } \\
\text { evaluation of scientific policy } \\
\text { Health Research Fund }\end{array}$ \\
\hline FNDICYT & $\begin{array}{l}\text { National Fund for the Development of Scientific } \\
\text { and Technical Research }\end{array}$ \\
\hline $\begin{array}{l}\text { IMADE } \\
\text { MAPA }\end{array}$ & $\begin{array}{l}\text { regional development agency of Madrid } \\
\text { Ministry of Agriculture, Fisheries and Food }\end{array}$ \\
\hline MEC & Ministry of Education and Science \\
\hline MSC & Ministry of Health and Consumer Affairs \\
\hline PATI & $\begin{array}{l}\text { Industrial and Technology Action Plan (Ministry } \\
\text { of Industry and Energy) }\end{array}$ \\
\hline PEICU & $\begin{array}{l}\text { Programme of Institutional Evaluation of the } \\
\text { Quality of the Universities }\end{array}$ \\
\hline PSOE & Spanish Socialist Party \\
\hline
\end{tabular}

Monitoring and Evaluation) structure which is used in the UK.

Because practices, procedures and institutional arrangements for research evaluation are still developing, some of the report by the $\mathrm{OECD}^{4}$ (Organisation for Economic Co-operation and Development) for the Italian evaluation scene could be extended to Spain. But in Spain, as in France, ${ }^{5}$ the state acts as guarantor of the self-organising activity of the actors in the public R\&D system.

The evolution of research evaluation activities or practices could be viewed as embedded in the institutions for governance of the R\&D system and in the general characteristics of the system for making public policy. In that general way we may discuss path dependent properties of the trajectory of development of $R \& D$ evaluation system in Spain.

\section{Stability and change in state action}

A necessary condition for development of research evaluation and RTD policy evaluation, if some institutionalisation of the practices is expected, is the existence of public policies in support of S\&T and of development of the R\&D system itself.

At the end of the Franco period the S\&T system was underdeveloped: total R\&D expenditure accounted for $0.4 \%$ of GDP (gross domestic product), research was significant only in public laboratories, with very little involvement of firms and almost no research activities at the universities.

For financial reasons, state research activity was limited to funding public research centres through direct budgetary appropriations. There was no explicit S\&T policy, with no support of research and technological activities through independent bodies such as Research Councils, or in the form of strategic R\&D programmes. Development of professional research control practices had been limited and subordinated to political support. Setting up research evaluation as professional practice had been growing with the return of researchers trained in the USA at the end of the 60 s.

The inheritance of the Franco era was the late and slow development of R\&D evaluation. Also, the political and policy-making system ${ }^{6}$ were not very sensitive to ideas such as policy evaluation, accountability or responsiveness. In summary, before the reforms of the 80 s there was no relevant $R \& D$ policy evaluation, because no $R \& D$ policy existed. The practice of research evaluation as professional control of the research community was weak because the research system was underdeveloped and subordinated to the authoritarian government.

\section{Evaluation as part of the $R \& D$ system}

In trying to identify and explain the different degree of development of research evaluation and R\&D policy and programme evaluation practices we have to take into account some variables exogenous to the research system. The general characteristics of the policy-making system are relevant. For example, Spanish policy-making is characterised by a tradition much concerned with legality and less committed to efficiency. Therefore formal evaluation practices were not very diffused in the Spanish public policy process. $^{\text {? }}$

The characteristics of the S\&T policy domain ${ }^{8}$ as an institutional configuration embedded in the R\&D system and defined by organisational properties and for players or actors interacting could have a more direct impact on research evaluation.

S\&T policy refers to government initiatives, deliberate actions with substantive RTD-related intentions, explicitly designed to develop, support and encourage science, technology and innovation. For many years the purposeful action by the state in favour of research was on the basis of delegation. The most primitive form was related to direct funding of research centres, while a more developed form took place with the development of some intermediary bodies (such as Research Councils) or funding agencies (NSF) working as the 'Republic of Science'? The choices and the management of the research system were delegated to the scientific community itself.

In this framework, most of the research evaluation and control activities could be seen as part of the professional and scientific mechanism of self-control. In most countries the competition for funding had been developed in the $60 \mathrm{~s}$ and $70 \mathrm{~s}$, while in Spain, until recently, no significant state funds for basic research were distributed in a competitive way.

In the 80 s a new way of managing the research system, including technological programmes ${ }^{10}$ and strategic $R \& D$ programmes had been developed in many countries. With these new management structures the traditional forms of evaluation research, such as peer review, were not enough; new management tools for control and decision-making were needed. The problems are not only scientific quality or relevance of the project, but also evaluation of 


\section{In Spain both delegation and strategic R\&D were developed at the same time, in the mid-80s, with similar instruments and in the same institutional framework: at this time the main focus of evaluation was on the development of a peer-review system}

success, achievement of objectives and determination of impacts and effects.

A new form of research evaluation, R\&D programme or policy evaluation, distinct from the delegated evaluation of academic science, began. Evaluation of RTD policy could be seen as a set of activities to determine to what extent that policy contributes to the success of S\&T in the light of certain given evaluation criteria. Evaluation includes assessment of goals, instruments and impacts of policies; a central part of the analysis is a comparison of what happened after implementing the programme with what would have happened if the programme had not been implemented, comparing the state of the world with the counterfactual and determining whether the policy made a difference, and, if so, in what way.

In Spain both delegation and strategic R\&D were developed at the same time, in the mid-80s, with similar instruments and in the same institutional framework. In that situation, due to the absence of a research evaluation system, the main focus was on the development of a peer-review system, with the guarantee of the state, as a mechanism for research evaluation.

R\&D actors and policy entrepreneurs first set up a fair and equal opportunities system for access to funding and positions through evaluation of research. The rapid growth of R\&D resources and the lack of consolidation of bureaucratic R\&D policy-making structures helped to underestimate the problem of $\mathrm{R} \& \mathrm{D}$ policy and programme evaluation.

Today we observe a tension between the concepts of R\&D evaluation as 'professional research control of the scientists themselves' and as 'professional evaluator or bureaucratic activity', but both forms are part of the same policy domain.

\section{Recasting the rules and institutions}

At the end of the $70 \mathrm{~s}$, with the transition to democracy, a major change occurred in the relationships between state and society in Spain. All those elements of democracy such as freedom of criticism, parliamentary control, accountability, legitimate domination, and so on started to work for the transformation of the political and policy-making systems.

\section{Changing environment for state action}

Some other structures had been also transformed, three of them specially significant in relation to opportunity and conditions of development of a S\&T policy and research evaluation:

The first structural change was the transformation of the size and functions of the state in the overall Spanish economy. In 1973 total public expenditure represented only $23 \%$ of GDP, in comparison with an average of $38.6 \%$ for European OECD countries. In 1993 the share of public expenditure in GDP had increased to $48.4 \%$. This growth in the 80 s provided the finance for S\&T policy that previous attempts lacked."

A second process, with lagged effects, was the incorporation of Spain into the European Economic Community (EEC) in 1986. European and Community models and ideas for support of RTD played a significant role in the selection of national $R \& D$ priorities, especially in the design of $R \& D$ programmes. The Second R\&D Framework Programme, 1987-1991, was a source of inspiration for the First Spanish National R\&D Plan, 1988-1991. The contact between Spanish representatives in this policy area and the European Commission was important in the evolution of policy leaming. Spain had been a significant recipient of EEC structural funds, but the relative impact on the Spanish R\&D system and the promotion of impact or evaluation studies had been less important than in Portugal and Greece. ${ }^{12}$

However, the most important change for the future management and governance of the research system in Spain was the new role of the Regional Governments. Democracy brought quasi-federalisation. Regions have competencies for legislative action in many areas, including "promotion of R\&D for regional interest" and "support of innovative activities in the region". Regional governments act in the promotion or management of research and the development of programmes of support for academic research activities and innovation in firms. This meant that regions were acting as financial partners in many R\&D activities, estimated at more than $10 \%$ of the total Spanish R\&D expenditure ${ }^{13}$ - a similar level to the total state funds for RTD strategic programmes and non-oriented research.

\section{Time for reforms}

The October 1982 victory of the socialist party (PSOE) opened a policy window and a time for reforms. In research policy the ideas behind those reforms were modernisation of the institutional structures and development of the $R \& D$ system. More financial resources and policy innovations were the means of action.

The process of modernisation of universities was developed by the University Reform Law (LRU) passed in 1983. This supported and promoted a process of change: the research university as a model; 
quality of research as the main criterion for academic careers; departments as central units of academic life; economic incentives to work under contract for the private sector; and so on.

The Law also regulated the self-government of the universities by the university community, but sustained the idea of public universities and civil service conditions for professors. Universities can now act in the R\&D system as differentiated players, because they are independent of the Government. Because of this enhanced capability for strategic management, differentiation and competition between universities were expected.

Some changes in the economic environment affected the incentive structure of firms for RTD activities. New laws and regulations were passed by Parliament to adjust Spanish normative structures to European ones, some of them very relevant for the property rights related to $R \& D$ and innovation activities, such as the Patents Law or the Intellectual Property Law passed in 1986 and 1987 respectively.

The public research laboratories had also changed over this period. First because they had almost lost their central postition in the public R\&D system in favour of the universities. Second, because the 1986 Law for the Promotion and General Co-ordination of Scientific and Technical Research (Law of Science) made some organisational reforms and attributed to those research centres a main role as direct instrument for central Government on S\&T policies. The National Centre for Scientific Research (CSIC) is the biggest of these public centres.

\section{Political institutions for research policy}

The most important reform and innovation was the organisation of a S\&T policy in the form of a National R\&D Plan. The Law of Science, approved in 1986 began the reorganisation of the public policy-making system in S\&T. This focused on the means of supporting S\&T from the state, and in the means of solving the problems of co-ordination between the aims of the different actors (such as universities and firms) and in particular between different R\&D mission-oriented policies of the ministries of central Government.

The framework for the new political institutions for S\&T was defined as 'co-ordinated'. Co-ordination was pursued in the decision-making process, establishing a new political body, the Interministerial Commission for Science and Technology (CICYT), ${ }^{14}$. with authority to define national $R \& D$ priorities and control international relations in scientific and technological activities. Co-ordination, and precise selection of R\&D priorities, was organised through the National R\&D Plan that allocated funds through programmes.

The aim of the reformers and policy entrepreneurs was to concentrate the national R\&D planning on the new CICYT. The institutional design for co-ordination was criticised ${ }^{15}$ because it had no authority over the ministries and it was very much dependent on the existence of a strong incentive structure and policy entrepreneurs for efficient work.

The CICYT managed and allocated the National Fund for the Development of Scientific and Technical Research (FNDICYT), representing between 6 and $8 \%$ of the total Spanish R\&D expenditure.

The First National R\&D Plan, 1988-1991, started as an aggregation of $R \& D$ programmes for financing research activities of $R \& D$ actors from universities, firms or public laboratories, mostly through instruments such as R\&D projects, infrastructure (scientific equipment) projects, firms and public laboratory R\&D co-operative projects and personal grants.

A relevant part of $R \& D$ support by the central Government was concentrated under control of the CICYT. However a few ministries, though represented in the CICYT, developed their own R\&D programmes, some included under the overarching National R\&D Plan. The Ministry of Education and Science (MEC) had integrated in the framework of the National R\&D Plan two R\&D programmes, one related to "training of researchers" and the other to "general promotion of knowledge", open to any type or topic of R\&D research.

The Ministry of Health and Consumer Affairs (MSC) had its own R\&D programme under the name FIS (Health Research Fund) which has been incorporated recently into the framework of the National R\&D Plan. The same applied to the Programme in Agrarian and Food R\&D from the Ministry of Agriculture, Fisheries and Food (MAPA).

There are still some difficulties in co-ordinating policies and the practice of research evaluation. For example, the Ministry of Industry and Energy has built up its own framework programme, an overarching Industrial and Technology Action Plan (PATI), that covers many specific programmes (electronic, pharmaceutical, new materials, biotechnology, and so on) addressed to firms. The Ministry of Defence is allocating resources for R\&D, but in association with its procurement programmes for defence systems. Because of the federalisation process, regional governments started to innovate and to develop their Regional R\&D or Innovation Plans.

The reinforcement of co-ordination of R\&D programmes and the common $R \& D$ management helped to build up a set of common and accepted procedures

\section{A relevant part of $R \& D$ support by the central Government was concentrated under control of the Interministrial Commission for S\&T, but a few ministries developed their own R\&D programmes, some included under the overall National R\&D Plan}


of research evaluation. It did not matter that, in this period of reforms, the idea of evaluation was secondary, because the main issue was the growth of resources and co-ordination of policies. Research evaluation was relevant only as a way of guaranteeing the faimess of the funding system.

The recently approved Third National R\&D Plan, 1996-1999, has improved its formal co-ordination procedure with some mission-oriented R\&D programmes and the general orientation to strategic research.

\section{Institutionalisation of research evaluation}

The description of the reforms in the R\&D system highlights some relevant issues in the new research policy, and specially the simultaneous initiation of the traditional funding of research and the new strategic R\&D programmes.

The reforms in the R\&D system and the innovations in R\&D policy-making contributed to the introduction and extension of ideas related to research evaluation. A new generation of researchers and $R \& D$ actors was needed to urge the establishment of research evaluation as professional practice. It was only in the 80 s that research evaluation started to be practised in a systematic way, as a self-organising mechanism and as a professional control instrument of the research communities. In that way research evaluation has been embedded in the overall $R \& D$ public policy system.

In that period, characterised by the growth of public funds, there was little concern with the efficiency or the effectiveness of R\&D programmes. Now the situation is different and for the future, in a context of budgetary restrictions, $R \& D$ policy evaluation will be pushed by policy-makers and officials of the Ministry of Economy and Finance, and also by interested social scientists. The new type of strategic R\&D programmes has created the conditions for development of new management competencies and opened the opportunity for R\&D policy evaluation practices.

The next section examines some of the procedures, practices and institutions of research evaluation that have been growing in recent years in Spain, and have played a critical role in providing information and mechanisms for control and management of the R\&D system.

\section{Research evaluation guarantee by the state}

The original purpose of the state's systematic introduction of research evaluation through peer review was to improve quality control of research and fair funding.

One of the major concerns of the reforms was to reward the best researchers. Explicit social and economic incentives were needed to attract people to research activities, and to recognise professional competence through prizes and rewards. Most of the policy entrepreneurs were academics or researchers, who trusted the capability of the scientific community to select the best proposal, to evaluate the quality of the research, and to predict and assess the effects of the policies.

The reforms produced two institutions ${ }^{16}$ that are relevant: the National Evaluation and Assessment Agency (ANEP - Agencia Nacional de Evaluación y Prospectiva) and the National Commission for Evaluation of the Research Activity (CNEAI Comisión Nacional Evaluadora de la Actividad Investigadora). In September 1995, the Council of Universities approved a Programme of Institutional Evaluation of the Quality of the Universities (PEICU - Programa de Evaluación Institucional de la Calidad Universitaria).

The ANEP is an institution in the CICYT, the political-planning body in charge of $R \& D$ policy, but with an autonomous management. The ANEP is concerned with: ${ }^{17}$

\begin{abstract}
"the scientific and technical evaluation of entities and research groups that participate in the implementation of programmes and projects of the National R\&D Plan, the proposals of both $R \& D$ actors and operators, and the monitoring of results (outputs and outcomes) that could be produced in the development of those programmes and projects."
\end{abstract}

The Agency also has legal responsibilities for forecasting and foresight in scientific research and technological development. Up to the present, the bulk of ANEP activity has been scientific and technical evaluation for project selection and funding, general scientific and technical assessment and technical advice to political bodies, with some evaluation of research institutions.

Research-project evaluation is mostly done on the basis of formal ex ante peer review, with a written report addressing the quality of the proposal, the experience and the adequacy of the research team, a judgement on the budget, and some other items. Another kind of evaluation is organised on the basis of peer-review panels, and is used most of the time in individual funding assessment, for instance, graduate student grants. About 20,000 R\&D actions were evaluated for financial support last year, including 7,000 research projects

The ANEP, as an administrative agency, has a very light bureaucratic structure with few permanent officials. It maintains a large database of more than 10,000 Spanish and foreign researchers who are used as evaluators. There are 19 co-ordinators, working part-time, organised to cover different scientific and technological areas of knowledge: they play a role in selecting the reviews and membership of panels. Coordinators come from academic research activities.

ANEP has carried out few ex post evaluations, though an implicit evaluation of this type is done in 
project evaluation when considering the past record of the researcher and team. Some analyses of the performance of departments in the demands of funding for research through competitive methods has also been done.

A few evaluation exercises have developed at the request of some universities or centres, supported by a peer-review system and sometimes panel judgements, with the aim of ex ante evaluation of the proposed opening of a research centre or institute. Last year ANEP developed ten institutional R\&D evaluations of this type. ANEP can only work following a request, first from the CICYT and then from some other $R \& D$ organisations or funding bodies.

The positive development is that institutional practice supported by the ANEP (as a reliable system of determination of quality, significance and feasibility of the proposals) is being used increasingly by many different public administrations (different ministries and regional government or universities) and private institutions wishing to be sure of the faimess of the evaluation. Also there is a general acceptance in the scientific community, but it has been criticised because there are vefy few researchers in the database from firms. The agency recognises its lack of competency to develop technological evaluation for the moment, but the system that supports the ANEP is now providing more and more legitimisation for funding decisions.

There are some structural difficulties in the development of R\&D policy evaluation based in the ANEP itself. The small administrative structure of the ANEP, with half a dozen permanent staff, is almost exclusively involved with the management of project selection through peer evaluation, without monitoring or ex post evaluation of results. Yet ANEP could contract extemal R\&D policy evaluators, as it does with peer review and panel procedures, to develop the research programme evaluation activities commissioned by the different policy-making bodies.

In this hypothetical case ANEP would have difficulty in contracting evaluators, because there is no professional group of R\&D policy evaluators in Spain yet, and little resource to develop one. There are also methodological and technical difficulties in the development of the R\&D policy evaluations, but the most important is, for the moment, the lack of clear political will.

The CNEAI was institutionalised as a mechanism for evaluating academic careers and the research performance of researchers. It was organised in 1989 as a way of providing salary increases for university professors and CSIC researchers, who are civil servants. It defines an incentive for excellence in research activity, providing public recognition of good performance and resulting in a small increase in remuneration.

Once a year an individual researcher, from a university or public laboratory, with a PhD and tenure, can ask for an evaluation of his/her personal career

\section{The criteria and organisation of the CNEAI evaluation reinforce the scientific view of research and the academic concept of careers, neglecting a more applied view of research and more technologically oriented careers}

and curricula. The analysis of performance is made over periods of six years by a panel of peers, organised into 11 technical committees. Criteria of accomplishment in any of the research areas is publicly available. If the panel considers that the professional performance and quality in the period evaluated is sufficient, the researcher is granted a pass, a 'sexenio' (six years) recognition (five such rewards are the limit in the professional life). This represents a very important element of prestige and legitimisation and a small increase of salary.

Some criticism has been made to the CNEAI, because the criteria and organisation of the evaluation reinforce the scientific view of research and the academic concept of careers, neglecting a more applied view of research and more technologically oriented careers. There is a tendency to add to the importance to the CNEAI activities, with scientists and policymakers trying to reinforce the position of the CNEAI in the processes of recruitment of researchers at universities and research centres, introducing positive evaluation by the CNEAI as a condition for tenure.

The PEICU has recently been approved. The CNEAI, in its first year of activity, aggregated the results of the success/failure evaluation by research centres and universities, adding the individual results. These results are diffused, not published. The reaction of most of the universities cut off the development of this system as a way of rating the different research institutions and disciplines.

With the autonomy of the universities recognised in the Constitution, there was no direct state control of the quality of research activities of universities or research centres. But in September 1995, as part of the new funding system for universities, the Council of Universities, the collective body of regulation, approved the implementation from 1996/1997 of a new system of evaluation: the PEICU. Public money for the managers of the universities had become an incentive for further development of evaluation practices, always guaranteed by the state.

\section{Evaluation of $R \& D$ organisations}

The reforms highlighted evaluation for project selection and career evaluations, but also allowed the CICYT or ANEP to develop evaluations of R\&D 
organisations. It was not a clear mandate, because these organisations, in particular universities, are recognised in the Constitution as autonomous. However, the practice of research evaluation has been used experimentally in areas associated with the management of R\&D organisations.

University professors and researchers in public laboratories are civil servants. Once the researcher has a position, no matter what his/her performance may be, there are only disciplinary procedures open to remove him/her. Under these conditions, the management of the $R \& D$ organisation has very limited authority. Because R\&D managers or Chancellors are democratically elected, there is a serious constraint on the development of strategic management or R\&D evaluation.

Beyond those constraints, a number of centres and universities have been trying to develop some evaluation of the potential, strengths or competencies of their R\&D organisations. These experiences and practices of $R \& D$ evaluation have been very dependent on the capabilities for independent management of the organisations, for building progressive coalitions, and on the leadership of the Chancellors.

For example the Universidad Autonoma de Barcelona commissioned the ANEP to carry out a departmental evaluation to help decision-makers. Peer review, panel and interviews were used. In that university, the attempts of the Chancellor to develop a strategic policy, independent of his constituencies, finished with an electoral defeat. The Universidad de Barcelona has created a Department for Analysis that has been developing and co-ordinating evaluative activities and building up a database system, to provide knowledge for the decision-making processes of the managers. ${ }^{18}$

In the same way, the Studies Department (Gabinete de Estudios) from CSIC has carried out studies, analysis and evaluations of their institutes. In this case, the President of CSIC has more power to order R\&D evaluations of institutes and centres, because he is appointed directly by the Government. Some specific R\&D evaluations of institutes and centres have been commissioned. Sometimes these evaluations had been understood as punitive by the researchers themselves, because they were made in relation to some restructuring processes.

The procedures were developed under international or national panels that interviewed and analysed researchers and groups. Although the president of the CSIC can commission R\&D organisational evaluation, the problem is in implementation of the recommendations, because of the professional nature of the organisation. Since the mid-80s the CSIC has been concerned with building up a system of indicators to measure the performance and results of the different research centres, ${ }^{19}$ but still there is a serious shortage of data for R\&D evaluation for management.

These experiences have shown that $R \& D$ evaluation could be, and is, a powerful instrument for strategic R\&D management in universities and laboratories, now independent actors in the R\&D system.

\section{$R \& D$ programmes and policies}

A strong commitment was made by policy entrepreneurs to support the institutionalised system of evaluation of R\&D activities, mostly through peer review with the guarantee of the state, as the self-organising and selection mechanism in the R\&D system.

However, the 1986 Law of Science gave responsibility for elaboration, implementation, evaluation and monitoring of the National R\&D Plan to the CICYT, the organisation with real competencies for developing an R\&D programme of policy evaluation. CICYT must also present an "Annual Report of monitoring of the National R\&D Plan to the Government to be sent to the Parliament. This Annual Report must include proposals for reorientation".

Starting from 1988 a detailed and analytical Annual Report has been presented. Using the terminology of policy analysis it looks more like a monitoring document than a systematic evaluation. Of course, the Annual Report provides critical information for the next year's management and it is the base for lowlevel changes and adjustments.

Analysing the technical difficulties of $R \& D$ programme or policy evaluation, it is clear that $R \& D$ programmes have been ill defined, in terms of management and results evaluation, with no clear verifiable objectives. More important than the technical difficulties are the political ones. There is a need to find policy entrepreneurs who support the development of these exercises, internal or external, that are not the regular course of action of the dominant style of public management.

No formal or explicit decision of the CICYT taken to systematically evaluate $R \& D$ programmes has yet been included in the National R\&D Plan. But at the policy-making body some processes similar to policy evaluation could be identified. First, the organisational design to define the scientific objectives of the different programmes: panels and groups of experts, mostly clients of the programmes and very few users of knowledge were mobilised. Second, there is an administrative monitoring, with analysis and accounts of results, with substantial information on inputs (financial cost, researchers, and so on), but not much information about output of $R \& D$ processes or their-socio-economic effects.

This level of formal evaluation of R\&D programmes and policies is a result of the lack of policy entrepreneurs supporting $R \& D$ policy evaluation, the methodological difficulties, the poor design in evaluative terms of the programmes and the lack of political will, more than a lack of informed criteria for decision-making.

CICYT is not the only R\&D programme management body. RTD programmes included in the PATI from the Ministry of Industry and Energy have not been evaluated. There is much analytical work done 
on the evolution of different $R \& D$ programmes, a lot of information in relation to the industrial innovation activities and the competitiveness of Spain, but no $R \& D$ programme evaluation. It should be mentioned that the Centre for Technological and Industrial Development (CDTI), an agency for the management of some aspects and instruments of the RTD programmes of the Ministry, had commissioned external consultants to perform some broad evaluations of its activities.

R\&D programme evaluation is still a rare activity in the policy-making departments. There are no evaluation units or specific bodies. Usually studies departments carry out some of these activities in an informal way. There is no evidence of attempts to build up specific units of policy-programme evaluation in the different ministries.

The General Accounting Office (Intervención General del Estado), as budgetary and accounting office of the Ministry of Economy and Finance, is only concerned with control and accounting analysis. The Accounting Court (Tribunal de Cuentas), an independent organism of control of public expenditure, is also much concerned with legal issues and accounting procedures of state expenditure.

The Ministry of Economy and Finance is starting to introduce competition between programmes as a way of reducing public expenditure and it has begun to produce some management performance indicators to help in the decision-making process for allocation of budgetary resources.

Finally, we may note the increasing importance of the actions taken by the regional governments, as policy innovators. For example, the Regional Government of Madrid (Comunidad de Madrid), after starting the R\&D Regional Plan, 1989-1993, commissioned a White Book ${ }^{20}$ containing an evaluative study of the impacts and objectives accomplished by the Plan in comparison with $R \& D$ resources. Also the IMADE (the regional development agency of $\mathrm{Ma}$ drid) commissioned an evaluative analysis of the clients of their technological programmes. ${ }^{21}$

\section{Evaluative studies of $R \& D$ policies}

The National R\&D Plan has not had its programmes formally evaluated, but S\&T policy evaluation is included in its priorities. Thus the Plan is financing

\section{$R \& D$ programme evaluation is still rare in policy-making departments; studies departments do some informal evaluation but there is no evidence of specific units of policy-programme evaluation being built up in the different ministries}

the development of many studies and research projects in this area and is helping to build up academic competencies in ' $R \& D$ policy and programmes evaluation' as a research field.

I call them 'evaluative studies' because they are not formal evaluations as stages of the policy cycle. In general, they have not been formally commissioned, and are not integrated or associated with the decisionmaking processes; some of them achieve informal acceptance and collaboration of the policy-making body, but with no commitment to implement the results. There is a fear of the so-called 'political use' of the results that is consistent with the argument that organisations usually try not to question their objectives very often, specially when they are very much linked to a single client, no matter that this type of R\&D programme evaluation could offer some usefully instrumental learning.

A second point is that design of the study corresponds to an academic exercise more than a research evaluation. These projects lack an evaluative design to provide a clear definition of the purpose of the evaluation and clear evaluative criteria related to the aims and objectives of the programmes. They have the form of studies more than evaluations, in the sense that design is not participative and no confrontation of the views of the evaluated, clients and users is systematically organised.

Methodologies have not developed adequately. Most of them have had to work and analyse data on the monetary inputs of the programmes, determine the results and process the data. Sometimes a questionnaire has been passed between clients of the programmes, in which case the evaluation expresses the views of the clients. Many of the studies lack even a simple causal model of theeffects attributed to policy, and thus are unable to determine the effects of policies and actions. Up to the present, identification of additionality 22 effects has not attracted the attention of researchers.

These activities related to policy analysis have been growing in number and could be organised with different objectives. Some of the studies have addressed the problem of evaluation of $R \& D$ policy in general. For example, evaluation of scientific policy $(E P O C)^{23}$ was developed as a regular research project sponsored by the National R\&D Plan, with the aim of evaluating the activities of the Plan. It concentrated on some aspects, not very much associated with the methodologies of quasi-experimental research, with a general diagnosis of the R\&D system and some insights about first outputs of the National R\&D Plan. Most of the analyses have processed published statistical data about R\&D (expenditures and human resources) and SCI (Science Citation Index) data.

Another research project of the National R\&D Plan, on evaluation of S\&T policy in Spain ${ }^{24}$ adopted broad approaches to the analysis of public policy, that could be identified more as political economy of S\&T policy than R\&D policy evaluation. Also, promoted by policy-makers in charge of science policy, some 
balance of the outputs of the National R\&D Plan has been developed. ${ }^{25}$

Another group of studies is related to the evaluation of the impact of European R\&D policy in Spain. An analysis was carried out, as part of international evaluation exercises, of Eureka's (European Research and Co-ordination Agency) economic and industrial effects, with the participation of a Spanish team. There was also been a very descriptive analysis of the effects of the Second EC Framework Programme in the Spanish S\&T system, ${ }^{26}$ and a general analysis of the Spanish R\&D system in the European context. ${ }^{27}$

A third line of development of these studies has been the evaluation of specific $R \& D$ programmes. Using focus groups techniques and questionnaires to clients, some R\&D programmes of the National R\&D Plan and the FIS Sectoral R\&D Programme have been studied. ${ }^{28}$

A fourth group is concerned with the evaluation of research fields, most of the studies concentrating in the use of bibliometric indicators for evaluative purposes. ${ }^{29}$

The last thematic group of consultancy work has included studies of the evaluation of the management of $R \& D$ policy-making bodies, mostly with the aim of justifying the activities of the $\mathrm{CDTI}^{30}$ in support of $R \& D$ in private firms.

Overall, a growth of interest in the topic can be detected over the last few years and a new evaluation of the CDTI activities is in progress.

\section{Perspectives for the future}

The development of research evaluation in Spain has shown a strong dependence on the degree of development of the $R \& D$ system and on the level of relevance of state action in S\&T policy. Political processes opened a policy window for reforms of the R\&D system and the setting up of a RTD policy. As a consequence of the reforms some elements of research evaluation institutions have been built by the state. The design of a S\&T policy included actions organised through delegation to the research communities in a non-oriented research programme and into strategic R\&D programmes.

Due to the historical lack of development of the practice of research evaluation, the peer-review system guaranteed by the state appeared to the actors in the late $80 \mathrm{~s}$ as the central element in the introduction of research evaluation in the R\&D system. Research evaluation has been developed as a mechanism for self-organisation of the research community, with the guarantee of the state. Most of the practices and institutions set up addressed individuals or groups of researchers or R\&D actors.

The introduction of some elements of differentiation and competition between universities and research centres, linked to the funding system, has helped the institutionalisation of the evaluation of some of the R\&D operators. Evaluation of R\&D institutions came onto the agenda later, thanks to the support of the state, and there have been some developments and experience in this area.

During the years of expansion of the public budget for research, the underdevelopment of the public bureaucracies in charge of RTD policy, the lack of tradition in the Spanish public administration of efficacy and effectiveness evaluations as part of the policy cycle, and some other elements, helped to position the R\&D policy and programme as a second-order priority. Even now there is little development of the systematic practice of R\&D policy and programme evaluation, though it has been introduced onto the agenda.

Structural elements which favour the development of evaluation practice are:

- the growing differentiation between researchers, and managers and policy-makers of the R\&D programmes;

- the strong budgetary constraints in future years which is creating open competition for public funds; good technical design and management control of the policies will be a central element of the consideration of the Ministry of Economy and Finance;

- the introduction in the Spanish public administration of the culture of evaluation as part of the policy cycle;

- the influence of the European practices of R\&D evaluation;

- the development of public interest about the results and effects of $R \& D$ policies.

All these elements and tendencies are necessary but not sufficient conditions. The pace and the rate of development of the types of R\&D policy or programme evaluation will be very much dependent on elements such as:

- the existence of some policy entrepreneurs in the R\&D system that could push for the development;

- the availability of professional R\&D evaluators;

- the improvement in the design of $R \& D$ programmes; and

- the establishment of a system of indicators useful for management control and R\&D policy evaluation.

Finally the Spanish case confirms the centrality of the state in the setting up and development of practices of research evaluation, and the decisive role of political variables as external shocks to the R\&D system.

\section{Notes and references}

1. M Callon, $P$ Larédo and $P$ Mustar, "Introduction générale", in $M$ Callon, $P$ Larédo and $P$ Mustar (editors), La gestion stratégique de la recherche et de la technologie. L'évaluation des programmes (Economica, Paris, 1995) pages 9-24. 
2. $R$ Barré, ' $L$ ' évaluation de la recherche et la régulation des relations science-technologie-societé", in $A$ Esterle and $L$ Schaffar (editors), Organisation de la Recherche et Conformisme Scientifique (PUF, Paris, 1994) pages 213-262

3. For an analysis see, in this issue, the contribution by $P$ V Hills and $A$ Dale, "Research and technology evaluation in the United Kingdom", Research Evaluation, 5(1), 1995, pages 35-44.

4. See OECD, Reviews of National Science and Technology Policy. Italy (OECD, Paris, 1992), or the contribution in this issue by $A$ Silvani and G Sirilli, "R\&D evaluation in Italy: a science and technology policy view", Research Evaluation. 5(1), 1995, pages 69-77

5. P Mustar and $P$ Larédo, "La France et le modèle du garant", in $M$ Callon, $P$ Larédo and $P$ Mustar, see reference 1 , pages 89-102.

6. The best analysis of the inheritance is R Gunther, Public Policy in a No-Party State (University of California Press, Berkeley, 1980).

7. For example, see $X$ Ballart, Como evaluar programas y servicios públicos? (MAP, Madrid, 1992), or J Subirats, Análisis de pollticas públicas y eficacia de la Administración (MAP, Madrid, 1989)

8. It is assumed that the policy process and changes are determined mostly, but not always, by forces within each domain. For a review of the literature see P Burstein, "Policy domains: organization, culture, and policy outcomes", Annual Review of Sociology, 17, 1991, pages 327-350

9. M Polanyi, "The republic of science", Minerva, I(1), Autumn, 1962 , pages $54-73$

10. M Callon, $P$ Larédo and $P$ Mustar, see reference 1; and A Rip, "Implementation and evaluation of science and technology priorities and programmes" in SE Cozzens, P Healey, A Rip and $J$ Ziman (editors). The Research System in Transition (Kuwwer, Dordrecht, 1990) pages 263-280

11. OECD, Pollticas nacionales de la ciencia. España (MEC, Madrid, 1971)

12. See the contributions is this issue by $M$ da Silva and $L$ Henriques, "R\&D evaluation in Portugal", Research Evaluation, 5(1), 1995, pages 80-97, and $N$ Kastrinos and $Y$ Katsoulacos, "Towards a national system of research evaluation in Greece", Research Evaluation, 5(1), 1995, pages 63-68.

13. This calculation was made by CICYT, The System of Science and Technology in Spain (ClCYT, Madrid, 1995).

14. Re-gaining the ministerial department that existed for a couple of years at the end of the 70s (Ministry of Universities and Research - MUI) was one of the objectives of some of the policy entrepreneurs, but after negotiations within Government it was considered not realistic or politically viable.

15. OECD, Innovation Policy: Spain (OECD, Paris, 1987) criticised the excess of normative orientation of the reforms, and some researchers criticised the fragile institutional design: see L Sanz Menéndez, E Munoz and C E Garcla, "Los problemas de coordinación en la Politica Cientifica y Tecnológica: Liderazgo y coordinación", Revista del Centro de Estudios Constitucionales, 15, May-August, 1993, pages 161-181.

16. There is a description of the practice in X Ballart, "Evaluación de la investigación cientifica: el caso español", paper presented at the Conference Innovazione e processi di riorganizzazione nell politiche delia ricerca scientifica, Rome, 19 December, 1994.

17. Royal Decree $415 / 1987,6$ March, "Organic structure of the
Permanent Commission of the CICYT"

18. See $C$ Viladiu et al, "A research evaluation model of a large ancient university", Research Evaluation, 2(3), December pages 124-134.

19. See, for example, L Sanz Menéndez and J Pfretzschner "Política cientifica y gestión de la investigación: EI CSIC (1986-1990) en el sistema español de ciencia y fecnología", Arbor, 557, May, 1992, pages 9-52.

20. See the works by E Munoz, L Sanz-Menéndez and V Larraga (1993), published as Libro Blanco sobre la Polftica Cientffica en la Comunidad de Madrid (CAM, Madrid, 1993).

21. The study had been published under $M$ Molero and $M$ Buesa, Patrones de cambio tecnológico y polltica industrial (Civitas, Madrid, 1992).

22. See L Georghiou and J S Metcalfe, "Evaluation of the impacts of European Community research programmes upon industrial competitiveness", R\&D Management, 23(2) 1993 or T J Buisseret, H M Cameron and L Georghiou, "What difference Buisseret, H M Cameron and L Georghiou, "What difference
does it make? Additionality in the public support of R\&D large firms", International Joumal of Technology Management $10(4 / 5 / 6), 1995$, pages $587-600$.

23. See some of the results published in M A Quintanilla et al " $E$ sistema español de ciencia y tecnologla (EPOC)", special issue of Arbor, 554-555, February-March, 1992.

24. See some results in $L$ Sanz-Menéndez, $E$ Muñoz and $C E$ Garcia, "The vicissitudes of Spanish science and technology policy", Science and Public Policy, 20(6), December, 1993, pages 370-380; L Sanz-Menéndez and E Muñoz, "Technolpages $370-380 ; \mathrm{L}$ Sanz-Menéndez and E Muñoz, "Technology policy in Spain: issues, concerns and problems", in $G$
Aichholzer and G Schienstock (editors), Technology Policy: towards an Integration of Social and Ecological Concerns (De Gruyter, Berlin-New York, 1994) pages 349-374; or L SanzMenéndez, "Policy choices, institutional constraints and policy learning: the Spanish science and technology in the eighties", Intemational Joumal of Technology Management, 10(4/5/6), 1995 , pages $622-641$

25. See the report by $A$ Lafuente and $L$ Oro, "Evolución del sistema de ciencia y tecnología en España. El Plan Nacional de I+D", in $\mathrm{R}$ Dorado et al (editors) Ciencia, tecnologia e industria en in R Dorado et al (editors) Ciencia,

26. A Bravo et al, "Estudio de impacto de la política de $1+D$ de la CE en el sistema español de ciencia y tecnologla (Salamanca, mimeo, 1994).

27. A Lafuente and L Oro, El sistema espafiol de ciencia y tecnologla en el marco internacional (Fundesco, Madrid, 1991).

28. Just to mention some of them, see J Espinosa, E Munoz and $\checkmark$ Larraga, Una valoración de la Investigación en Biomedicina y Salud en España (CSIC-IESA, Madrid, 1993, 2 volumes); J Espinosa et al, El programa nacional de investigación y desarrollo farmaceutico durante el periodo 1988-1993 (CSIC-IESA, Madrid, 1995); or J Espinosa et al, El programa nacional salud en el periodo 1988-1993 (CSIC-IESA, Madrid, 1995).

29. See for example the more general works I Gómez, E Sanz and A Méndez, "Utility of bibliometric analysis for research policy: a case study of Spanish research in Neuroscience", Research a case study of Spanish research in Neuroscience", Research
Policy, 19, 1990, pages 457-466; or A Méndez, I Gómez and $M$ Bordons, "Some indicators for assessing research performance without citations", Scientometrics, 26(1), 1992, pages 157-167.

30. See the publication by E Fontela, A Pulido, M P Sánchez and $J$ Vicens, Evaluación de la actuación del CDTI en apoyo a la I+D (CDTl, Madrid, 1992). 